\title{
Preface to Third Edition
}

It's a very good thing that readers don't see the soil out of which the lush blooms of books spring. However lovely the flowers and green the grass, soil is soil and dirt is dirt. Reading The Ethics of Deconstruction now, some twenty-one years after it was first published and twentyfive years after I had the first inkling of its argument, I find it remarkable how little dirt is visible.

Let me try to rectify that a little. When I graduated with a degree in philosophy from the University of Essex in 1985, I decided that I wanted to study in France, as most of the books I was reading were either in French or were translated from French. I had the choice between Paris and Nice, as a couple of my teachers had contacts there. I chose Nice simply because of the climate. I struck an informal and illegal deal with my teachers at Essex. I would stay on and do a Ph.D. at Essex as long as they let me go away to France for a year, maybe two. In other words, I would stay as long as I could go.

My plan was simple and devious. Because I got a good enough degree, I received a grant from the British Academy for three years (this funding was easier to get back then). I was totally obsessed with philosophy and with Derrida in particular, but I knew there was no future in academia as there had been no jobs in the UK since the late 1970s. So, I would take the money and run. After a decent length of time, my partner and I would abandon academia and live in the sunshine on the Côte d'Azur.

Things did not really work out as planned. We got most of our belongings stolen on the drive down to the south of France. Nice was an awful, mean, right-wing, racist place. The university was a shithole. The students were dull and conformist. We couldn't find work and we didn't even speak French.

But I did meet Dominique Janicaud. For reasons that still escape 
me, he was wonderfully kind and patient and gave me tutorials every two weeks on a text of his choosing. He knew that I was interested in Derrida but thought I should work on a more general, philosophical theme. Although a Heideggerian, Dominique had very heterodox views and was deeply interested in the question of the overcoming of metaphysics. What did that locution really mean?

Dominique suggested that I enroll for the M.Phil. in philosophy in Nice and write a dissertation on the question of the overcoming of metaphysics in Heidegger and Carnap. Back then, nothing had been written on this topic and I was arguably well-placed as I could read English well and German badly. It took me over a year to write the dissertation in French and it ended up being a document of 200 pages. It was a world of pain. But along the way, I learned how to do research, how to make notes and how to really use a library.

What was in the back of my mind while writing the M.Phil. dissertation was the link between the overcoming of metaphysics in Viennese positivism or Heidegger's later thinking and Derrida's concept of the closure of metaphysics that was a persistent theme in his work. This was the germ of the idea for chapter 2 of The Ethics of Deconstruction, which is the oldest stratum of the book. I was intent on placing Derrida's work within a genealogical context of the history of metaphysics and not reducing deconstruction to some formalistic method of reading, based around the location of binaries or whatever. By this time, I had decided that life in the sunshine was horrible and wanted to go back to the grey misery of England and write the Ph.D. My partner, Anthea, was only too happy to leave and we arrived back by boat in late 1986. My initial idea for a Ph.D. thesis was to write something on Derrida's use of Kantian transcendental argumentation, namely his talk of conditions of possibility and impossibility. But I could not get enough traction for this idea. Next I thought I would write on Derrida's reading of Husserl, until I discovered how much Husserl had written and how little interest I really had in it.

Then I remember one evening in the bar at Essex with my long-time friend and former housemate, William Large. As undergraduates, we became experts in stealing books of French poetry from the university library. That evening we were drinking copious amounts of bitter beer and came to the decision that there were two outstanding philosophical problems that we needed to address: technology and ethics. I don't know what happened to technology, but ethics was obviously what 
I should be working on in relation to Derrida. Back then, everyone assumed that deconstruction was a form of relativism, scepticism or nihilism and had nothing to do with questions of ethical responsibility. I knew that was wrong, but did not know how to go about showing it.

Thanks to my teacher, Robert Bernasconi, I had written on Levinas as an undergraduate and he had made a huge impression on me. I simply fell in love with the prose of Totality and Infinity. Finally, I thought, someone is writing the philosophy that I want to read and which deals with the topics of the highest importance. Robert had begun writing a book on Derrida's 1964 essay (monograph really) on Levinas, 'Violence and Metaphysics'. I never saw a copy of Robert's book, because it never appeared, although we talked about it a lot and his ideas were published in a number of important papers. This is the reason why I stay relatively clear of 'Violence and Metaphysics' in The Ethics of Deconstruction. My idea was that the latter would be a kind of companion to Robert's book.

In late summer 1987, I began to work on a paper on Derrida and Levinas. It was long, rambling and vague, but was essentially a commentary on some little-known texts and remarks of Levinas about Derrida that form the basis of chapter 4 of The Ethics of Deconstruction. I felt that an idea about the ethical dimension of Derrida's work was slowly beginning to take shape. Robert then asked me to revise the translation of Derrida's second essay on Levinas, 'At this very moment in this work here I am', for a book he was editing. Eventually, we edited the book together (it was called Re-Reading Levinas (1991)) and I wrote the first draft of what became chapter 3 of the book early in 1988 in an almost hallucinatory state over about ten days. By this time, I began to think that I had the beginnings of a Ph.D. thesis. I was working intensively, manically even, on the material in the central chapters of The Ethics of Deconstruction when a weird thing happened. I was offered a post-doctoral fellowship at Cardiff University in March 1988. But the condition of the fellowship - and this was a job with a salary! I mean actual money! I was going to get paid to think! - was not just having completed the Ph.D. thesis, but having defended it too. I spent the next few months writing furiously, had finished by July and defended in late September. By this time, Robert had left Essex for the USA. I disappeared into the endless drizzle of South Wales.

On the very day of my Ph.D. defence, after a hugely important conversation with Jay Bernstein (in fact, there were many such conversations over the years), I realized the problem with what I had 
written. I had arguably said some persuasive things about the question of ethical responsibility in Derrida by way of Levinas's work. That was maybe very nice. But what about political judgement? What was the relation between ethical responsibility and the question of politics? More particularly, and this was something I was learning from teaching with Ernesto Laclau, what was the connection between the structural undecidability of deconstruction and actual political decisions?

It took me a couple more years to be able to try and answer Jay's question - which is laid out in chapter 5 - which deals with questions of the relation of ethics to politics, radical democracy and community. Let me just say that it was the hardest part of The Ethics of Deconstruction to write. By this time, let's say 1991, I was back teaching at Essex, and had the first sense that maybe I could publish what I had written as a book. The problem was that I now hated the presentation of Derrida that I had attempted in the Ph.D. I decided to completely rethink my approach to Derrida's work, Levinas's relation to it and what was at stake philosophically and politically in this relation. This led to the first fifty pages of the book, in chapter 1 .

By late summer 1991, everything was done and the book appeared in late May 1992, a couple of weeks before the birth of my son, Edward. This was when I had another piece of tremendous good fortune. Derrida was initially denied an honorary doctorate at Cambridge University. This might be difficult to believe now, but Derrida was suddenly front-page news and the status of that weird thing called 'deconstruction' was a topic of intense polemic and debate. I remember the headline from the Independent newspaper on 17 May 1992 after it was finally decided to grant the doctorate to Derrida: 'Cognitive nihilism hits English city'.

So, the matter at hand was whether deconstruction was nihilism, namely the undermining of all that was great and noble about the Western tradition [yawn]. It just so happened that I had written a book which argued that Derrida's work had to be understood as an ethical project in Levinas's sense, that it was universalistic and not relativistic, and that it has serious consequences for the way we think about democracy. It was the very opposite of nihilism. So, The Ethics of Deconstruction had a lucky birth. These things simply cannot be foreseen.

What also could not have been foreseen was the reaction of Derrida. Because Dominique knew him well from the early 1960s in Paris onwards, I met with Derrida a number of times and enjoyed a cordial 
correspondence with him, with letters written in his almost indecipherable handwriting. He was always encouraging and supportive. But after I sent him The Ethics of Deconstruction I heard nothing. I waited and still nothing. I was bitterly disappointed, as I thought I had written the book in defence of his work against his many critics. I wanted some narcissistic gratification from Derrida.

Some time passed. Then, in May 1993, I was due to be part of a discussion in Paris with Ernesto Laclau, Chantal Mouffe, Richard Rorty and Derrida on the topic of deconstruction and pragmatism. I was absolutely terrified at the prospect of speaking in public in such august company. I didn't sleep the night before and was sitting in a café before the event, feverishly going through my notes. Derrida suddenly walked in and ordered a coffee: 'Une noisette,' he said. He saw me and we began to talk. I was very nervous. He then said, after ten minutes or so, 'About that book you sent, I didn't know what you wanted from me.' He repeated the words, 'I didn't know what you wanted from me'. I still don't know what he meant, but I interpreted it as a chronic sensitivity to what he saw as the critique of his work in the final chapter of The Ethics of Deconstruction. The problem was that I did not see that chapter as a critique, but as an essential element of dislocation in what I was calling clotural reading. I saw my book, then, as a gesture of fidelity to Derrida. After the Paris seminar, everything got back to normal between us, but I will never forget that moment of amazement, particularly when so much of the book is concerned with the logic of the gift and what it is to receive a gift. Now I think that his apparent ingratitude was the most ethical gesture.

I would like to thank Carol Macdonald, Eddie Clark, James Dale and all at Edinburgh University Press for making this Third Edition possible. I would also like to thank Hannes Charen for a great deal of help reading proofs. We have added three new texts: (i) the full-length version of my obituary for Derrida that only appeared in excerpts here and there; (ii) a paper on Levinas's relation to Heidegger, which is an important topic that was not adequately dealt with in The Ethics of Deconstruction originally; (iii) a paper which tries to identify and analyze what I now see as the major problems in Levinas's work, particularly in relation to politics. I seek to show how Derrida's later writing on Levinas might be seen to address and even rectify some of those problems. This last text is a kind of inversion of the argument of The Ethics of Deconstruction. It is important to me. 
Delighted as I am to see The Ethics of Deconstruction in print in a beautiful new edition, with a handsome cover by my friend Liam Gillick, I must confess that I find it a difficult book to read. When I begin to scan the sentences and flip through the pages, I become overwhelmed with the memory of how hard it was to write and what I felt like when I was writing it (i.e. lousy, anxious, insomniac). I hope any future readers do not feel the same. 